\title{
Exploration on the Integration of Local Culture into College English Teaching
}

\author{
Qiu Jie \\ Shaanxi Xueqian Normal University, Xi'an, Shaanxi, 710100
}

Keywords: local culture; colleges and universities; English teaching; cultural communication

\begin{abstract}
With the development of times and social progress, universities have been undertaking the mission of cultural transmission in the process of English teaching, which is of great importance to the spread of traditional culture. At present, college English teaching in China mainly focuses on cultural transmission of foreign developed countries, which seriously ignores the spread of local culture in English teaching, and has a certain impact on Chinese college students' intercultural communicative competence. Therefore, colleges and universities in China should effectively integrate the local culture into English teaching, to improve students' ability of telling Chinese stories in English.

In college English teaching, students are more familiar with western festivals such as Thanksgiving, Christmas and Valentine's day compared with traditional Chinese holidays like Dragon Boat and Mid-autumn festivals, let alone expressing them in English. The phenomenon of cultural imbalances is detrimental for spreading Chinese cultural abroad. With China's reform and opening-up, an increasing number of foreigners are shifting their eyes into China. Chinese herbal medicine, Peiking opera, calligraphy, qigong and taichi are popular with westerners. Thus, it is necessary to incorporate traditional Chinese culture into college English teaching, improve students' language proficiency in expressing Chinese culture in English. Further more, apart from English language learning and testing itself, learning extensive and profound Chinese culture will inject new vitality into teaching process and motivate students to a greater extent.
\end{abstract}

\section{Introduction}

With the global economic development and social progress, the global integration of economy of our country is gradually developing, and to a certain extent between countries and all have established many cultural activities. The culture of China's five-thousand years of history, is an inexhaustible motivation to encourage the country. At this stage, although many of China's colleges and universities have gradually started to attach importance to cultural communication, but putting too much emphasis on the importance of foreign culture in English language teaching, to a certain extent, which causes a lot of students to ignore the local culture in the learning process of inheritance. Therefore, our local culture communication should be effectively integrated into the efficient English teaching process, which has become an important problem to study in English Teaching in higher education. college students can spread the local culture with English to promote the development of traditional culture [1].

\section{The present situation of local culture in College English Teaching}

By exploring the research and analysis on college English teaching, we found that English teaching in China has put more emphasis on foreign cultural education and communication. In this way, most Chinese college students do not pay attention to our local culture and the colleges has not spread the local culture education in English teaching, which resulted in the misunderstanding of the connotation of cross-cultural education.

The most obvious one is that our high school classroom English teaching is rarely connected with cultural curriculum, which can not let the students know about the local culture, cultural content and relevant documents on the school and the society involved is very small. So students 
have little understanding of Chinese culture esp. local culture. On the other hand, we can see that in the curriculum setting, the culture of the English speaking countries we have learned in English teaching is introduced in detail, occupying most of the class hours. However, in the dissemination and introduction of local culture, the course setting is only a few key institutions of higher learning. Again, most of China's colleges and universities in the choice of curriculum, English major teaching materials, also relate to foreign cultures, and for our local culture and communication mentioned are very few, which will result that, in a certain extent, our students have less understanding of the local culture and opportunity, and slowly evolved that students' knowledge of local culture is deficient, eventually making China's native culture long regrettably losing. [2]

English teaching in colleges and universities not only has little local culture education for students, but also has some problems in their native culture expression. Many college students can not use English to express their native culture independently, nor can they use English to inherit the local culture. On the contrary, many college students are very obsessed with the traditional western festivals and ignore the traditional Chinese festivals. Although these to a certain extent on college students in China for foreign culture and English ability of understanding, but for our understanding of the Chinese culture is less and less, even to foreign novels and literary works for China, know little masterpiece. Therefore, in the process of English teaching, the lack of local culture has been more and more serious in China's colleges and universities, which has seriously hindered the inheritance and development of Chinese traditional culture [3].

\section{The necessity of integrating local culture into College English Teaching}

The main purpose of offering English teaching courses in Colleges and universities in China is to let our culture communicate with foreign cultures, so as to better inherit and develop our culture. This is also a kind of cross-cultural communication, spreading the Chinese native culture to all over the world. College English learning has become an important tool for cultural exchanges, an important process to achieve the purpose of national development and prosperity. Nowadays, in the process of English teaching in China's colleges and universities, the communication of the local culture has gradually been intercultural communicative competence, which will eventually lead to the spread and development of some excellent ethnic cultures in China. At the present stage, in some developed countries abroad, their culture has gradually dominated the development of global culture. Therefore, our universities must have a deep understanding of the essential problems, and better propagate the traditional culture and local culture, and actively find measures to solve them.

Our country has a long history, and the traditional culture is very rich. At the present stage, the local culture has become the progressive soul of our country. As a cradle to cultivate the motherland, colleges and universities ignore the local culture and education, which will lead to the gradual decline of college students' moral values and values in the western countries, and ultimately the disappearance of our local culture. Therefore, China's higher schools should strengthen effective English teaching in the combination of the local culture, in the teaching process and teaching materials enter the local culture in preparation, so that our students can understand the local culture, to better improve students' moral quality and ideological consciousness, establish a correct outlook on life and values in the future life and work. [4]

\section{The reasons for the problems of culture in College English Teaching}

At this stage, in order to better meet the trend of cultural development in the world, the people of our country have gradually opened a trend of learning English. In such a big environment, on the one hand, it promotes cultural exchanges between China and foreign countries, but neglects our attention to local culture. Many college students, though having various English Certificates in their hands after graduation, will not be able to get the words with local culture in silk and porcelain. Because of higher education in the process of English teaching seriously miscellaneous subjective teaching of western culture, so a large part of the students are influenced by western culture, values and the final explanation of China's traditional culture deviates from these, we first set his mind 
instead of College English. At present, many effective English teachers lack the awareness of local culture and education, and have regarded English language learning as a simple English culture and knowledge point explanation. Even some teachers still exist some extreme ideas in English teaching, for example, unlimited praising western cultures and directly denying our traditional culture, on the one hand, which caused serious damage to China's traditional culture, on the other hand, seriously affected our understanding of traditional culture. The local culture in college wide dissemination and learning has been seriously affected, and has blocked the development of the comprehensive qualities of college students [5].

With economic development and social progress, culture has been integrated around the world. But at the present stage, there are still some cultural unequal situations in the society. They only focus on foreign culture, but do not spread and carry forward the local culture. This unequal cultural situation has seriously hindered the development of our national culture, and also stressed the western advanced culture and humanism, while the local culture is ignored. Therefore, the students adapt to the requirements of western cultures, to learn western teaching goal. In addition, when there are differences between Chinese culture and Western culture, some ignorant English teachers often blame students for their ignorance of western culture. Many reasons are attributed to our local culture. But few people have been able to put forward the contradiction between western culture and our culture. All of these are inequalities arising in the process of cultural transmission. In essence, this cultural exchange is not in line with our future development direction, and it is a failure [6].

Culture of a nation after a long history and the fruits of labor embodied, is the embodiment of national spirit and integrity, long-term practice and communication products of our country's peopl. Cultural communication and educational system are inseparable, and the establishment of education system and cultural communication are also very important. If we integrate culture communication and education, we will know that education and culture can shape talents that are suitable for social development and social needs at the present stage, and can also spread culture to a certain extent. Therefore, the purpose of education is to inherit the culture better, and the inheritance of education is to spread the culture more effectively. The ultimate aim of cultural heritage is to standardize and internationalize education. Under the guidance of college English teaching mode, China's education system is more focused on knowledge point teaching, while for local culture communication is little. In this way, education and cultural communication should be integrated and a complete system should be established.

\section{Integration of local culture and efficient English}

The teaching process of English Majors in Chinese colleges and universities can see that there are serious neglected situations in China's local culture transmission, which are mainly reflected in the following aspects. First, there is a deviation in educational ideas. Second, the mode of English teaching in colleges and universities is backward. Third, the content of English teaching leads to the imbalance of cultural communication. Therefore, aiming at the teaching of higher education in China, we should gradually strengthen the dissemination of local culture, and gradually break through the spread of local culture in the process of effective English teaching.

With the deepening of China's economic globalization, cultural exchanges between China and many other foreign countries have deepened. More and more people have realized the importance of learning English, and also have been able to cultivate intercultural communicative competence more effectively. So, in order to better fulfill the above-mentioned requirements, in the process of English teaching should not only strengthen the cultivation of students' skills, should also strengthen the cultivation of language ability of the students, help them establish a better outlook on life and values, which can accurately use English in cross-cultural communication, better in foreign cultures, in order to eliminate the contradiction between foreign culture and native culture. In addition, after establishing good intercultural communication theory, the students should also learn better in daily English learning process to express Chinese culture in English, and let more foreigners understand the history of our culture and our people's values, and thus achieve the 
purpose of communication and exchange.

On the one hand, we should pay more attention to the communication between English and culture, and we should input and analyze English culture to stimulate students' national spirit and national feelings. For teachers, we should not only have the ability to teach language knowledge, but also should help the students to understand the differences between Chinese culture and Western culture, to establish student's own values. Besides, in the English classroom, students also need to standardize the expression forms of local culture, so as to form more effective teachers, guide the classroom, gradually form strong intercultural communicative competence, and make effective use of multimedia teaching equipment to teach and communicate with local cultures. In the process of English teaching in colleges and universities, culture is a very common way of teaching, which can not only promote understanding between students of the two different cultural values, but also enrich students' cultural knowledge in the teaching process, to ensure the classroom learning. Internet can be effectively combined into teaching, which is an effective teaching way. What's more, our teachers should also improve their own teaching concepts and knowledge, actively develop curriculum research and innovation, so as to better train and export intercultural communication talents.

English course setting plays a very important role in English teaching. At the present stage, most of the syllabuses in our country's college English teaching can reflect the importance of spreading and inheriting the local culture, but there are also some instances of insufficient local culture. Therefore, in order to better enhance the importance and dissemination of our local culture, we must focus on every educational link and combine with English culture and local culture. In addition, we must make clear the syllabus, combine our national cultural values and traditional customs, and set up a certain system of English teaching mode according to different grades and different degrees of difficulty and degree.

Over the years, China's education system for the students in the English test, are mainly focused on speaking and writing in four aspects, which causes some college students think that learning English is just learning grammar knowledge, and for cross-cultural communication is ignored. Therefore, we should fundamentally reform English teaching, improve it from the source, start from many aspects, and gradually form the use of traditional culture communication level to improve college students' ability of expressing local culture with English.

\section{Conclusion}

In conclusion, with the development of times and the progress of society, foreign culture is coming into our country. Under such circumstances, if we want to ensure the effective dissemination of our traditional culture, we must do the following four points. First, establish the correct idea of intercultural communication. Second, we should strengthen the teaching method based on teachers. Third, local cultural settings should be strengthened in the setting of English courses in Colleges and universities. Finally, a test of native cultural competence should be expressed in English.

\section{Acknowledgment}

Fund Project: Scientific research project of Shaanxi Education Department, Research on the multi-dimensional sharing platform of Chinese culture

\section{References}

[1] Du C, Science S O. Discussion on the Integration of Mathematics Culture into College Mathematics Teaching[J]. Science \& Technology Innovation Herald, 2015.

[2] Xu L. Discussion on the Significance of Culture Guidance in College English Teaching[J]. Value Engineering, 2011. 
[3] Clarke B. Bergmann, Matthias, Institute for Social-ecological Research/Frankfurt and Wissenschaftskolleg-Institute for Advanced Study/Berlin, Germany[J]. Inidtd Org.

[4] Carla Chamberlin-Quinlisk. Cooperative learning as method and model in second-language teacher education[J]. Intercultural Education, 2010, 21(3):243-255.

[5] Rodrigo S, Millercochran S, Roen D. DIY Mentoring: Developing Personal Learning Networks[J]. 2014.

[6] Frech W J, Cooperman R A. What should we teach international business students about terrorism? [J]. International academy of business and economics, 2007, 7(4).

A brief introduction to the author:

Qiu Jie (1978. ), Female, Master, Native Place: Xianyang, Shaanxi Province, Vice-president of Sh aanxi Xueqian Normal University.

Research direction: English Curriculum and Pedagogical Theories 